\title{
A Late Carboniferous fossil scorpion from the Piesberg, near Osnabrück, Germany
}

\author{
Jason A. Dunlop ${ }^{*}, 1$, Carsten Brauckmann ${ }^{2}$ and Hans Steur ${ }^{3}$ \\ ${ }^{1}$ Museum für Naturkunde der Humboldt-Universität zu Berlin, Invalidenstraße 43, 10115, Germany. E-mail: jason.dunlop@museum.hu-berlin.de \\ ${ }^{2}$ Technische Universität Clausthal, Institut für Geologie und Paläontologie, Leibnizstraße 10, 38678 Clausthal-Zellerfeld, Germany. \\ E-mail: Carsten.Brauckmann@tu-clausthal.de \\ ${ }^{3}$ Laan van Avegoor 15, 6955 Ellecom, The Netherlands. E-mail: steurh@xs4all.nl
}

\begin{abstract}
Received 10 July 2007

Accepted 20 August 2007

Published 15 February 2008

\section{Key Words}

A new fossil scorpion - only the second from the Late Carboniferous (Pennsylvanian) of western Germany - is described from the Westphalian D of the Piesberg near Osnabrück, Germany. This slender and rather gracile specimen is very closely related to the stratigraphically contemporary Eoscorpius carbonarius Meek \& Worthern, 1868 from Mazon Creek, Illinois, USA and is here assigned to E. cf. carbonarius. A precise placement is hindered by the need for revision of the late Carboniferous scorpion fauna.
\end{abstract}

Pennsylvanian

Arachnida

Scorpiones

Eoscorpiidae

Eoscorpius

\section{Introduction}

The Late Carboniferous (Pennsylvanian) Coal Measures of Europe and North America have yielded nearly forty accepted scorpion species (Fet et al. 2000); over a third of the known fossil fauna. On the face of it, scorpions would appear to be one of the most diverse groups found within these Coal Measures environments. However, at least some taxa seem to be of questionable validity, having been raised for incomplete specimens and/or material which may have been altered taphonomically. A particular problem is the posthumous monograph of Kjellesvig-Waering (1986). The most wideranging revision of fossil scorpions, it offers a highly typological classification scheme in which numerous species were raised to monotypic genera and families based on reciprocal differences rather than explicit or convincing apomorphies. Important progress towards a more phylogenetic classification has been made (e.g. Jeram 1994a, b), but revision of all fossil scorpions within a cladistic framework remains a major goal towards understanding the early phases of scorpion evolution.
Compared to the United States, the United Kingdom and the Czech Republic, Carboniferous scorpions from Germany are rather rare. The Early Carboniferous of the Erzgebirge Basin in Saxony has yielded Eoscorpius bornaensis Sterzel, 1918. This widely overlooked name was not picked up in important summaries (Petrunkevitch 1953; Kjellesvig-Waering 1986) or catalogues (Fet et al. 2000), but the holotype - held in the Chemnitz Museum - was mentioned by Nindel (1955) and Brauckmann (1982), and refigured by Rößler \& Schneider (1997, fig. 11). It is, however, only known from the ventral surface. Another scorpion was described from the Late Carboniferous Coal Measures of Haltern in Nordrhein-Westphalia; an isolated carapace assigned to Alloscorpius wardingleyi (Woodward 1907) by Brauckmann (1982) and re-assigned to Mazonia wardingleyi by Brauckmann (2005).

Here, we describe a new and largely complete specimen of a scorpion from the Coal Measures of the Piesberg, near Osnabrück in Lower Saxony (Figs 1-2). Its slender and gracile morphology (Figs 3-5) is most reminiscent of the Mazon Creek species Eoscorpius carbonarius Meek \& Worthen, 1868, and pending a

* Corresponding author 


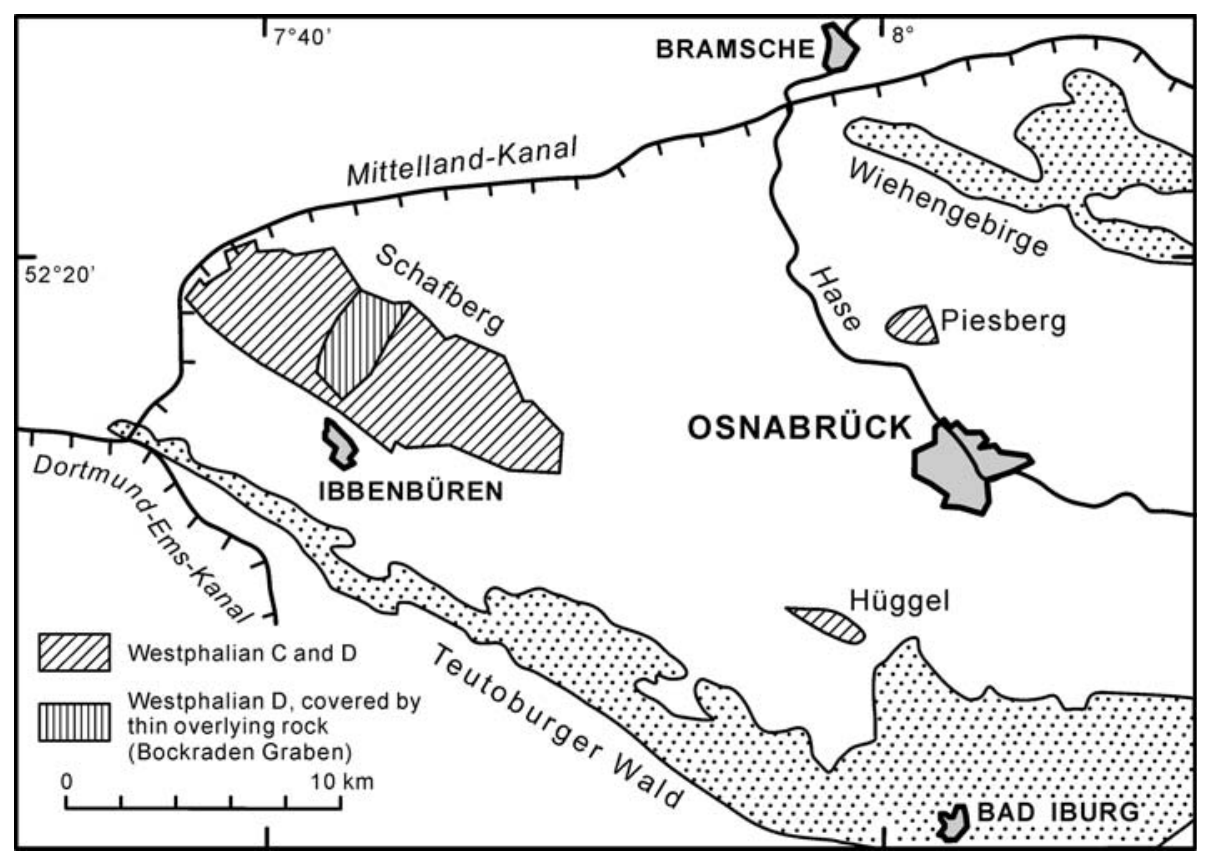

Figure 1. Schematic map showing the geological setting of the Westphalian C-D strata of the Piesberg region, to the north of Osnabrück (Lower Saxony, Germany). revision of this genus (and similar-looking taxa) it is provisionally assigned to this species.

\section{Material}

The new specimen described here (Figs 3-4) originates from the Piesberg (see below), near Osnabrück, Lower Saxony, Germany. It was collected by Mrs. Adri Delcour (Enschede, The Netherlands) and is presently held in her private collection. The final repository will be in the museum Natura Docet (Denekamp, The Netherlands) as specimen no. ND/AD200643. The specimen was drawn using a stereomicroscope with a camera lucida attachment and photographed using a Canon Eos 400D with a macro lens. The reconstruction (Fig. 5) derives some details, particularly of the legs, from published drawings of other Eoscorpius material - principally those in Kjellesvig-Waering (1986) - as well as comparisons with extant species.

\section{Geological setting}

The geology and stratigraphy, as well as the fossil content, of the Late Carboniferous (Pennsylvanian) sequence in the Osnabrück mountain region has recently been compiled by Köwing \& Rabitz (2005) and Brauckmann \& Herd (2003). The Piesberg north of Osnabrück, as well as the Schafberg near Ibbenbüren, are the northernmost outcrops of Late Carboniferous deposits in North Germany (see Brauckmann \& Herd 2003, fig. 1). The large Piesberg quarry is well-known for its very rich fossil flora and, over the last few years, as well as for its increasing number of insect remains (Brauckmann \& Herd 2003, 2006). It exposes a total sequence of about $210 \mathrm{~m}$ thickness of Westphalian D age (= Osnabrück Formation). Before 1898, when underground work was still ongoing, even older deposits of Westphalian $\mathrm{C}$ age were accessible. The whole sequence consists mainly of alternate beds of (partly coarse to conglomeratic) sandstone, siltstone and shale; it is subdivided by a number of coal seams (see Brauckmann \& Herd 2003, fig. 2) of which the 'Zweibänke' marks the base of the Westphalian D. Most of the plants and all of the insects were found in the shales above the respective coal seams. A detailed list of the fossil flora was recently given by Köwing \& Rabitz (2005: 266-267) and includes Equisetophyta (Calamitales and Sphenophyllales), Lycopodiophyta (Lepidodendrales), pterophylls (Filicophyta and 'Pteridospermae'), and Pinophyta (Cordaites).

The fauna includes, as already mentioned by Brauckmann \& Herd (2003) and references therein, Xiphosura (Euproops), Arachnida (Trigonotarbida: Aphantomartus pustulatus), Arthropleurida (Arthropleura), scales of fish (Palaeoniscidae), egg capsules of Chondrychthyes (Palaeoxyris) and a vertebrate tooth. Among the microfossils there are records of 'Conchostraca' (above the 'Mittel' coal seam) and Foraminifera (around the 'Itterbeck' coal seam). Non-marine Bivalvia (Anthraconauta) are very rare. The insects described by Brauckmann \& Herd $(2003,2006)$ occurred above the 'Zweibänke' and 'Dreibänke' coal seams, respectively.

Many fossils of the Piesberg are covered by a light film of guembelite (a variety of hydromuscovite) which creates a striking contrast to the surrounding matrix and makes the slabs, in particular those with larger plant remains, attractive to collectors and museums. The place where the loose block which yielded the scorpion was found, as well as the colour of the rock, make it most likely that it originated from a level within the clay stone layer above the 'Zweibänke' seam. The block includes many extremely well preserved specimens of Annularia radiata, but few other plant species. For this reason the block is not from the regular plant layer, but from somewhat higher in the sequence. 


\section{names of seams}

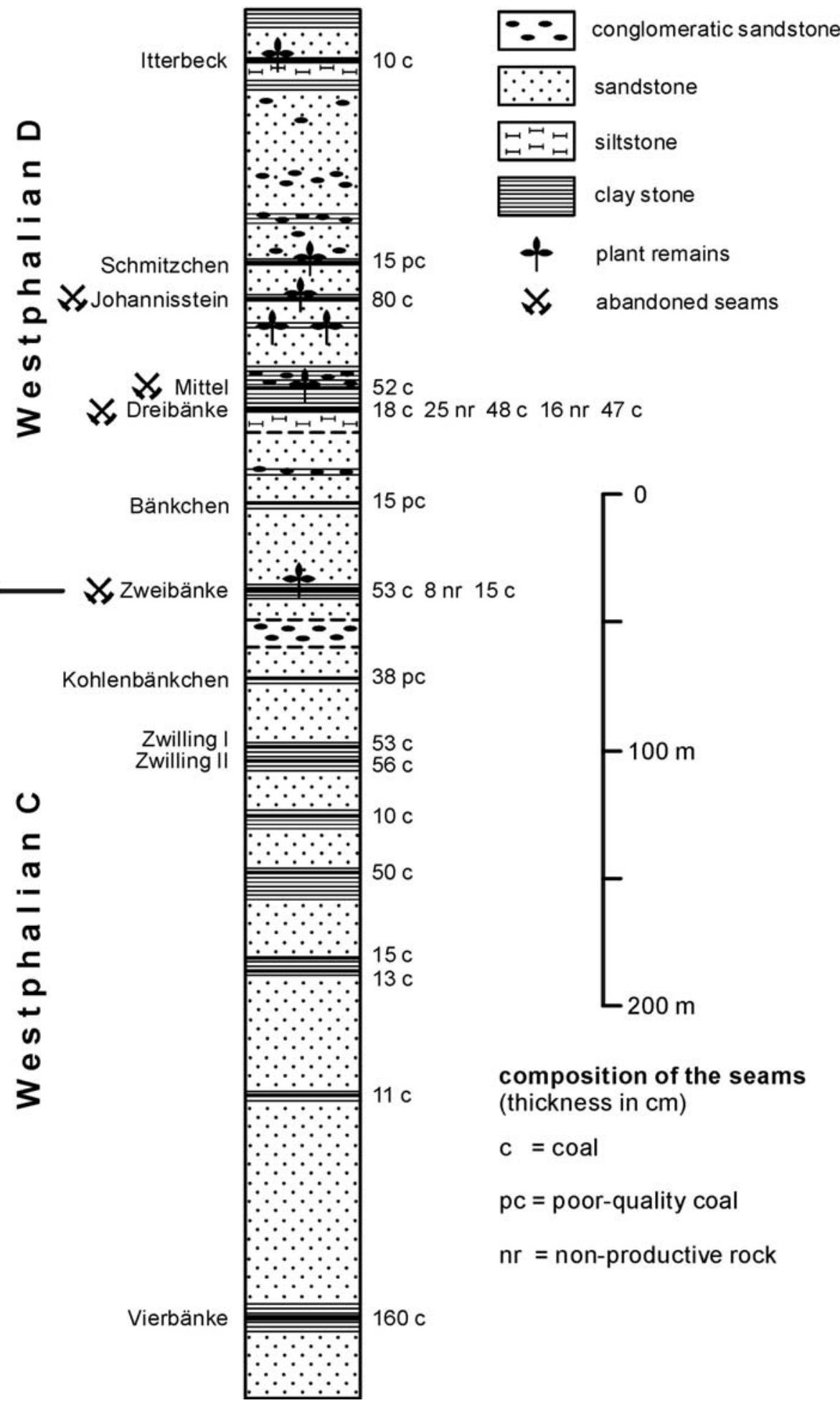

Figure 2. Geological section of the Piesberg. The scorpion fossil described here derives from the clay layers above the 'Zweibänke' coal seams and can thus be dated to the lower part of the Westphalian D.

\section{Morphological interpretation}

The fossil is largely complete, but split over a number of slabs which have, in part, been glued back together. Areas of original cuticle are brown against the dark grey matrix. The three most important slabs (illustrated here) show the anterior half of the body, the posterior half and an isolated pedipalpal claw respectively (Figs 3-4). The specimen is not as straightforward to interpret as it appears. The two body halves are, as noted on the figures, essentially part and counterpart being the dorsal surface in negative (anterior half) and positive (posterior half) relief. This is shown by, for example, the preservation of tubercles and ridges as depressions anteriorly, but as true ridges, as in life, posteriorly. There is a small amount of overlap between the part and counterpart - see particularly segment numbers 5 and 6 in Fig. 3 - which gives the superficial 

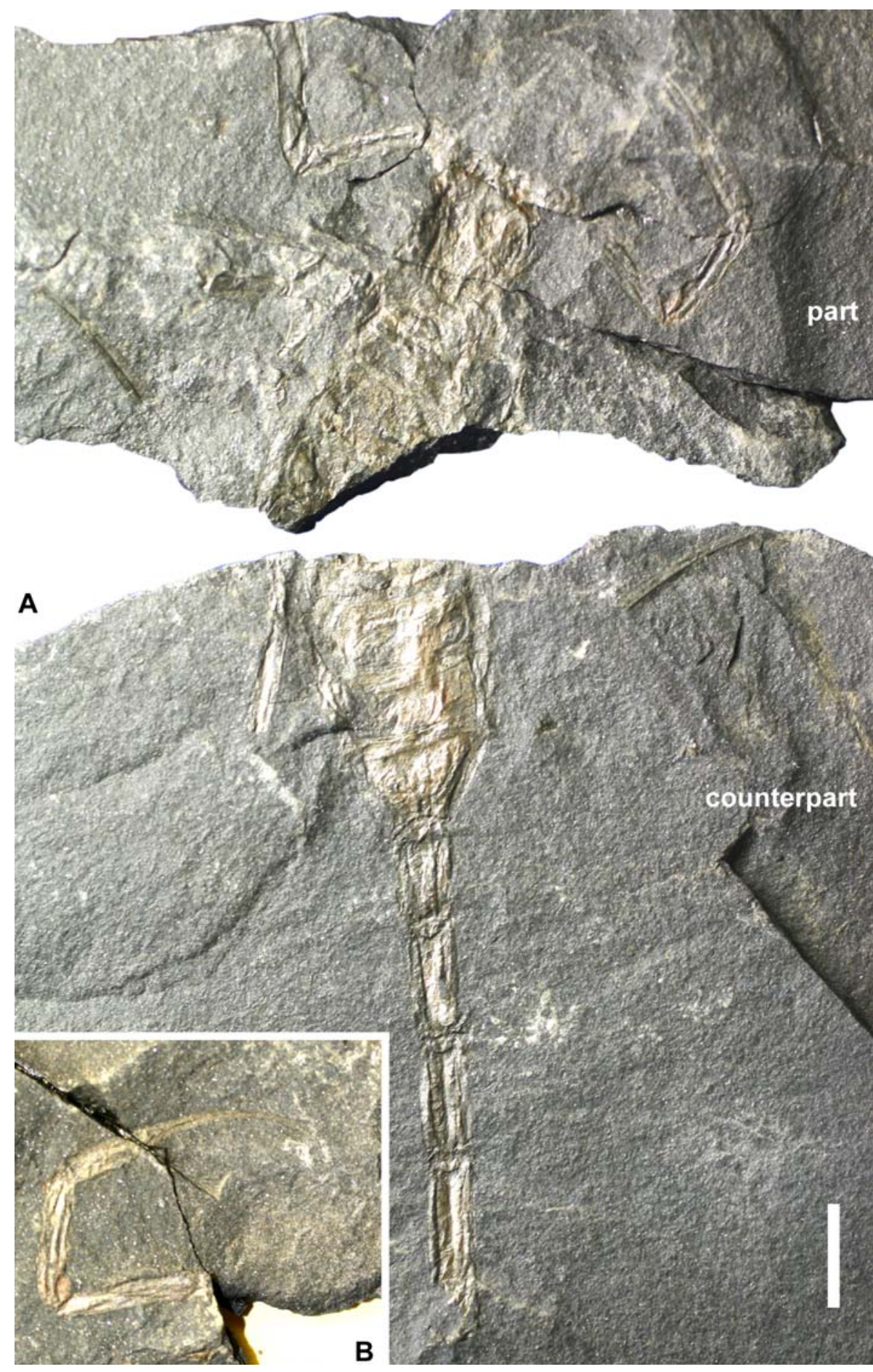

Figure 3. Eoscorpius cf. carbonarius Meek \& Worthen, 1868, an almost complete scorpion from the Late Carboniferous (Pennsylvanian: Westphalian D) of a quarry in the Piesberg near Osnabrück, Lower Saxony, Germany. A. The two main slabs, arranged adjacent to one another, showing the bulk of the body. B. Counterpart of one of the chelate claws showing its full length and proportions. Scale bar equals $10 \mathrm{~mm}$.

This figure is available in colour online at museum-fossilrecord.wiley-vch.de impression of the mesosoma being longer than it would have actually been in life (Fig. 5). Total body length was probably about $11 \mathrm{~cm}$.

Carapace. The prosomal dorsal shield, or carapace, is subquadrate with a raised, somewhat heart-shaped median region. This bears a pair of fairly large median eyes on an ocular tubercle set into a slight depression which merges and tapers posteriorly into a long median groove or sulcus, extending almost to the posterior carapace margin. Anteriorly there seems to be a slight pronouncement of the carapace in front of the median eye tubercle which would be consistent with its interpretation as an eoscorpiid (see Systematic Palaeontology). The lateral margins of the carapace are not well preserved, but the left anterolateral corner hints at a lateral eye tubercle (Fig. 4).

Pedipalpal claws. The pedipalps of the new fossil are remarkably slender. The trochanter has the usual, slightly bell-shaped appearance. Both the femur and patella have a pair of carinae. These carinae (or keels) are a typical feature of scorpion anatomy and are usually formed from rows of closely packed granules, although 


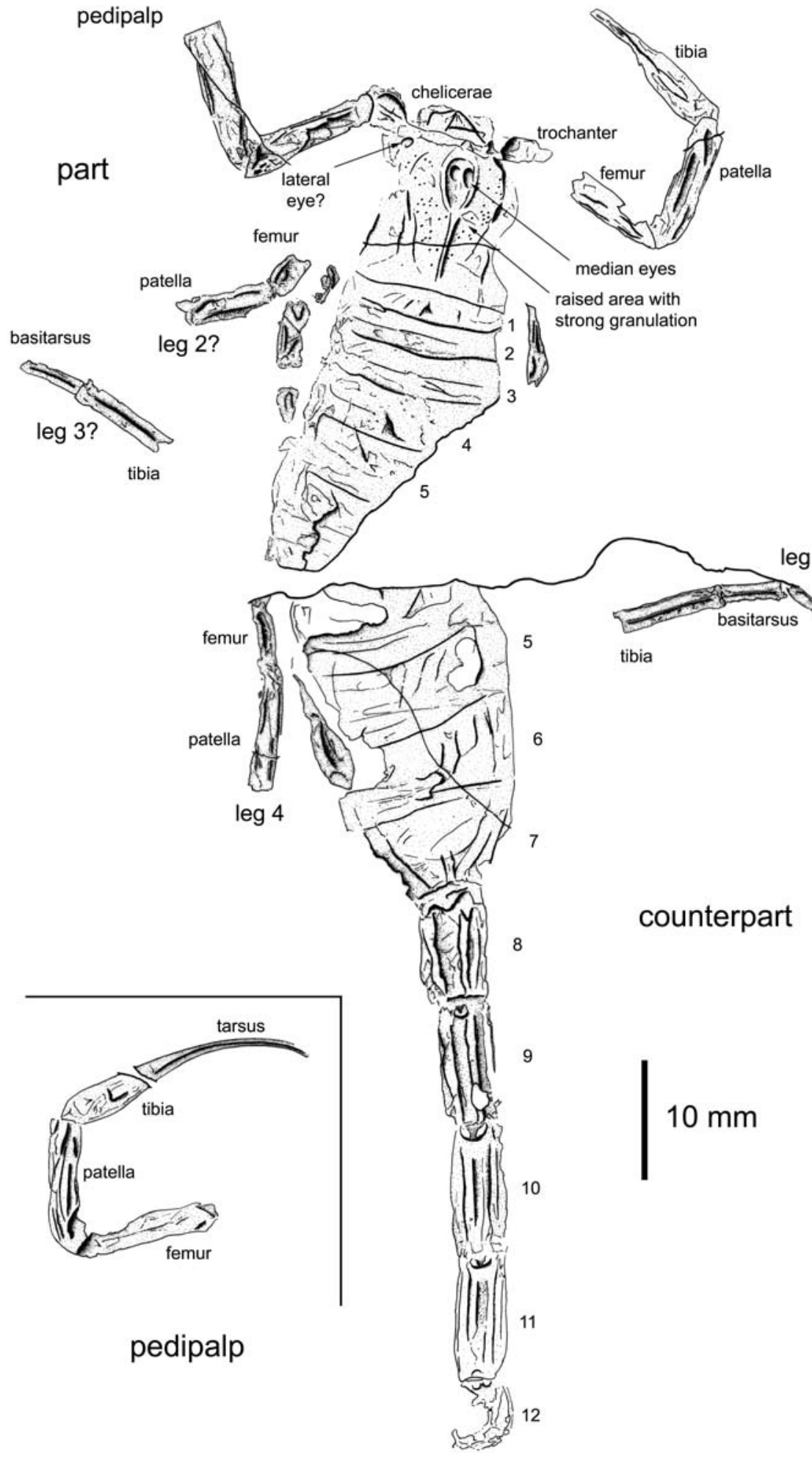

Figure 4. Camera lucida drawing of the specimens shown in Fig. 3. such individual elements are generally hard to resolve in fossilised remains. The scorpion pedipalpal claws are formed from the tibia (the manus and fixed finger) and the tarsus (the free finger) and can vary considerably in shape both among fossil and Recent species. In this fossil the 'hand' is noticeably elongate (Fig. 3B) with long, slender, gently curving fingers and only a slightly inflated base of the tibia. This basal region of the tibia bears hints of carinae too.
Legs. The legs are incompletely known, but enough fragments are preserved to gain a reasonable impression of their general shape and proportions. These suggest legs which were - like the pedipalps - fairly slender and gracile. The preserved femora and patallae bear a pair of carinae on what was presumably their lateral face, and a single prominent carina is also observed on the tibia and basitarsus articles. Only a single tarsus is preserved and the nature of the distal tarsal claws is 
unknown. These have been reconstructed based on comparable material, and tarsal and pedal spurs respectively at the distal end of the tibia and basitarsus have also been added in Fig. 5 based on other Eoscorpius species (cf. Kjellesvig-Waering 1986, text-fig. 70).

Mesosoma. The mesosoma - terminology after Farley (2001), alternatively called the preabdomen in some schemes - is generally taken to comprise opisthosomal segments 1-7. The first six tergites have gently recurved margins, and 2-6 seem to have a faint dividing line or sulcus extending across the tergite, although in places this is hard to disentangle from (?taphonomic) folds on the cuticle. Strong granulation or other sorts of ornament cannot be resolved. The seventh tergite tapers towards the metasoma and indicates at least one, probably two, pairs of carinae converging posteriorly towards the base of the tail. Such carinae on this segment are a consistent feature in all modern, and probably all fossil, scorpions.

Metasoma. The scorpion metasoma (postabdomen or 'tail') comprises five segments, plus the postanal telson which is modified into the venomous sting. Four seg-

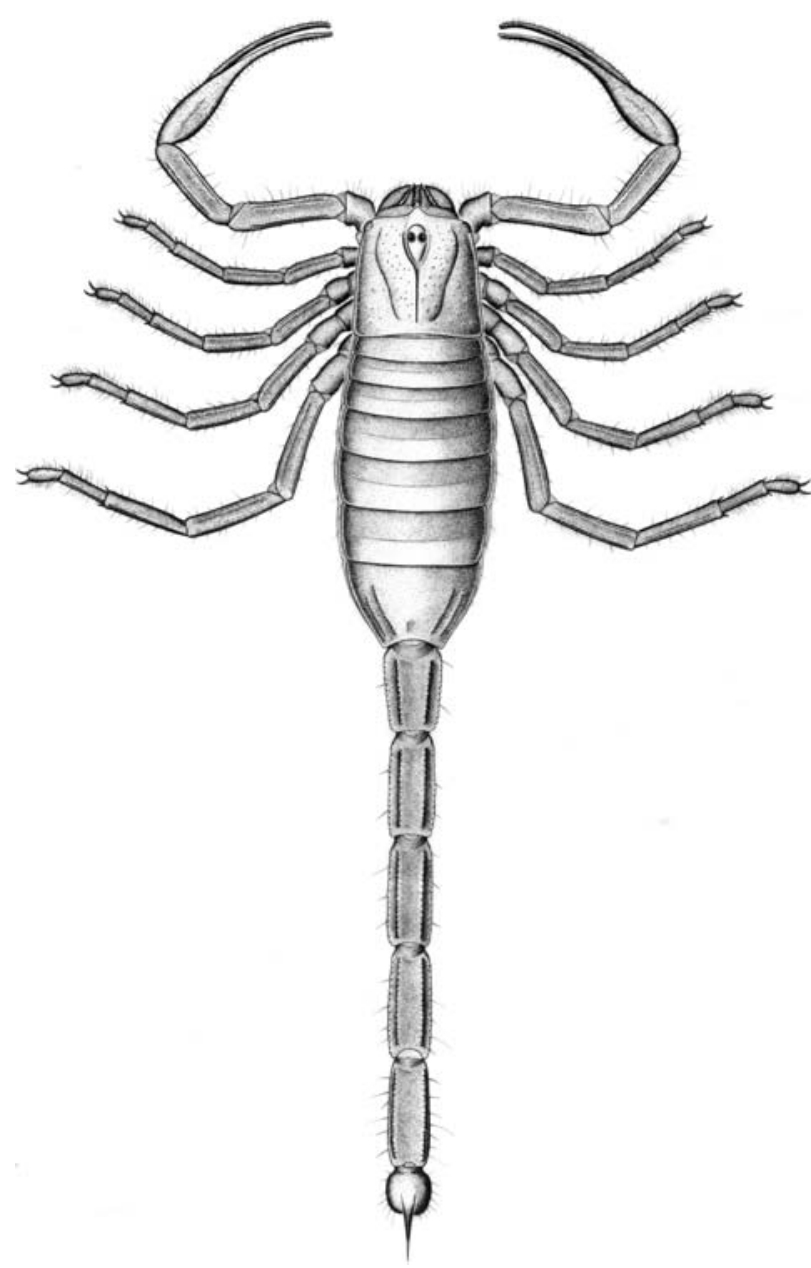

Figure 5. Sketch reconstruction of the probable appearance in life of the Piesberg scorpion, based in part on comparisons with other eoscorpiids as well as extant material. Total length in life around $11 \mathrm{~cm}$. ments, the first of which is visibly shorter than the following ones, are preserved in the present fossil and although the terminal element looks suspiciously like the sting, even being slightly hook-shaped, this must be regarded as the incomplete and distorted fifth metasomal segment. It is worth remarking that some fossil scorpions show an elongation of the fifth tail segment. This is a derived feature generally seen, to a greater or lesser extent, in all modern species and resolved by Jeram (1994a, b) as a defining apomorphy of a Neoscorpionina clade which incorporates all extant species. We have not included an elongate $5^{\text {th }}$ segment in the reconstruction since the only published illustration of Eoscorpius with a complete telson (Kjellesvig-Waering 1986, text-fig. 77) imply a $5^{\text {th }}$ segment about as long as the preceding $4^{\text {th }}$ one. However, we concede uncertainty on this point and note that the phylogenetic position of Eoscorpius is not clearly resolved in the Jeram hypothesis. The telson in the new fossil is presumed missing and is reconstructed (Fig. 5) based on extant species. Individual metasomal elements are ornamented by quite distinct and prominent pairs of keels, or carinae, which run along the length of the segments. Interestingly, the fossil also partially preserves the articulation between the metasomal segments - visible as a raised region at the anterior end of each segment - which contribute to the flexibility of the scorpion tail. Compared to most other late Carboniferous scorpion species, the metaso$\mathrm{ma}$ in this fossil is noticeably long and slender and contributes to the overall impression of a rather gracile animal.

\section{Systematic palaeontology}

\section{Family Eoscorpiidae Scudder, 1884}

Remarks. Eoscorpiidae currently comprises three genera: Eoscorpius, Eskioscorpio Kjellesvig-Waering, 1986 and Trachyscorpio Kjellesvig-Waering, 1986. The family was redefined by Kjellesvig-Waering (1986) based largely on a wide sternum and spatulate coxapophyses, i.e. projections of the leg coxae which form the floor of the pre-oral chamber. These ventral features cannot be resolved in the new fossil, but in carapace morphology - specifically the heart-shaped, inflated median region with its ornament of tubercles and the deep sulcus behind the median eyes - it most closely resembles fossils currently assigned to Eoscorpius. Among other Carboniferous families we found none which has representatives with such an obviously gracile morphology as the Piesberg fossil. Of the other eoscorpiid genera, Trachyscorpio is based on incomplete and composite material, regarded by Jeram (1994a) as a carapace fragment from a mesoscorpion - see Jeram's paper for definitions of major groups - plus some misidentified eurypterid fragments. Eskioscorpio supposedly had a smooth carapace with bulbous lateral eyes, but was noted by Jeram (1994a) as being a poorly preserved 
juvenile scorpion preserved in outline only. Both genera should probably be regarded as doubtful.

Indeed, a general problem with assigning any Coal Measures scorpion to a higher taxonomic group is the chaotic nature of Kjellesvig-Waering's higher systematics alluded to in the Introduction. Superficially similarlooking specimens became distributed across different superfamilies based on supposedly fundamental differences in the nature and configuration of the ventral mesosomal sternites, or abdominal plates in some interpretations. Taxa were often defined on character sets restricted to either the dorsal or ventral surface, or on elements like pectines which are not always preserved. Also, Kjellesvig-Waering (1986) almost exclusively used line drawings rather than photographs and the details in these drawings do not always tally with the actual specimens. It is not our intention to imply that all of this work is erroneous, but the families and genera of particularly the late Carboniferous scorpions merit thorough revision on a species by species basis within a framework of phylogenetic systematics. Jeram (1994a) presented an outline cladogram for the major groups, and Jeram (1994b) resolved relationships among the so-called orthostern genera - the most derived Palaeozoic forms - leading up to the modern scorpion crown-group. What has not been addressed in detail is the position of various putative mesoscorpion and/or palaeostern genera (including Eoscorpius) which represent the most frequently encountered Carboniferous scorpions.

\section{Eoscorpius Meek \& Worthen, 1868}

\section{Eoscorpius cf. carbonarius Meek \& Worthen, 1868} Figures 3-5

Synonymy. See Kjellesvig-Waering (1986, p. 163)

Material. Private collection of Adri Delcour (Enschede, The Netherlands), to be deposited in the museum Natura Docet (Denekamp, The Netherlands) as no. ND/AD200643.

Locality. Quarry in the Piesberg near Osnabrück, Lower Saxony, Germany

Horizon. Clay stone layer above the 'Zweibänke' coal seam, Osnabrück Formation. Late Carboniferous (Pennsylvanian: Westphalian D).

Description. Relatively complete specimen in dorsal view. Total preserved length c. $90 \mathrm{~mm}$ (excluding $5^{\text {th }}$ metasomal segment and telson). Prosomal dorsal shield subquadrate, length $13.8 \mathrm{~mm}$, with small median anterior projection and anterolateral (?eye) tubercle preserved at least on left side. Elevated median region approximately heart-shaped, maximum width $8.1 \mathrm{~mm}$, ornamented with moderately dense granulation. Elevated region bears relatively large (length $4.5 \mathrm{~mm}$ ), drop-shaped median ocular tubercle with a pair of prominent median eyes. Ocular tubercle encircled by a slight depression which merges posteriorly into a sulcus dividing the prosomal dorsal shield along the midline and almost reaching the slightly procurved posterior margin.

Elements of chelicerae preserved, but details lacking. Pedipalps gracile with bell-shaped trochanter. Femur $13.9 \mathrm{~mm}$ long, average width c. $2.5 \mathrm{~mm}$, expanding slightly distally. Patella $12.3 \mathrm{~mm}$ long and c. $2.5 \mathrm{~mm}$ wide. Both femur and patella ornamented with distinct carinae. Pedipalpal claw elongate and slender, total length $22.3 \mathrm{~mm}$, maximum width of tibia $2.3 \mathrm{~mm}$ with hints of carinae in basal region although tibia here not especially inflated. Fixed and free finger curve gently distally and no further ornament could be detected. Legs incomplete, but preserved articles indicate fairly slender appendages, width c. $2.2 \mathrm{~mm}$, in which the femora and patellae bore a pair of carinae. Distal region of one leg (?IV) with preserved article lengths in $\mathrm{mm}$ of: tibia, 9.3; basitarsus 5.4; tarsus 3.8. Tarsal claws unknown. Tibia and basitarsus both with one prominent carina, and both slightly inflated distally.

Opisthosoma divided into meso- and metasoma. Mesosoma with length c. $33 \mathrm{~mm}$; c. $15 \mathrm{~mm}$ wide anteriorly, maximum width $19.3 \mathrm{~mm}$, tapering posteriorly towards the base of the tail. Most tergites distinctly procurved, generally increasing in length posteriorly with individual lengths in $\mathrm{mm}$ of: $\mathrm{T} 1,2.3$; $\mathrm{T} 2,2.3$; $\mathrm{T} 3,3.8 ; \mathrm{T} 4,4.5$; $\mathrm{T} 5$, $6.1 ; \mathrm{T} 6,6.1 ; \mathrm{T} 7,8.1$. At least tergites $2-5$ with hints of a transverse division around half way down their length. Other ornament lacking, except for tergite 7 which bears one or two pairs of carinae converging towards the base of the tail and perhaps a slight median depression in the posterior half of the sclerite. Metasoma (tail) with maximum preserved length $43.2 \mathrm{~mm}$, width ranging from $5.8 \mathrm{~mm}$ anteriorly to $4.6 \mathrm{~mm}$ posteriorly. Four metasomal segments preserved with following lengths in $\mathrm{mm}$ : S8, 10.3; S9, 11.2; S10, 11.3; S11, 10.4. Segment 12 incomplete and telson equivocal. Preserved metasomal segments ornamented with distinct carinae, up to four of which are visible in dorsal view.

Remarks. The Piesberg fossil appears closest in overall morphology to the Mazon Creek species Eoscorpius carbonarius, which is likewise of Westphalian D age. Points of similarity include the long metasoma and the rather slender claws with long fingers, although it could be argued that the new specimen described here is even more gracile than its North American counterpart. Whether these differences merit a new species is harder to say. The new fossil lacks unequivocal autapomorphies separating it from other fossil taxa, and ratio and proportion-based characters are notoriously unreliable when comparing specimens under different modes of preservation (e.g. shales verses nodules as at Mazon Creek). Even within the published E. carbonarius material - discussed in some detail by Kjellesvig-Waering (1986) - there seems to be a certain degree of intraspecific variation. The type of one of its synonyms, E. typicus Petrunkevitch, 1913, shows proportions very similar to the Piesberg specimen; see also Petrunkevitch (1913, figs 5-6). For the reasons above, and given 
the problems with the systematics of late Carboniferous scorpions, we elect to assign the new specimen to Eoscorpius cf. carbonarius, pending wider revisions of both the European and North American material.

\section{Acknowledgements}

We cordially thank Mrs. Adri Delcour (Enschede, The Netherlands) who collected the specimen and made it available to us for description, Mrs. Irene Joss (Clausthal, Germany) who prepared the geological sketches and the reviewers, Erik Tetlie (Yale) and Paul Selden (Kansas), for helpful comments on the manuscript.

\section{References}

Brauckmann, C. 1982. Ein Skorpion aus dem westdeutschen OberKarbon. - Dortmunder Beiträge zur Landeskunde, Naturwissenschaftliche Mitteilungen 16: 27-30.

Brauckmann, C. 2005. 2.5 Ausgewählte Arthropoden: Insecta, Arachnida, Xiphosura, Eurypterida, „Myriapoda“, Arthropleurida und Trilobita. In Deutsche Stratigraphische Kommission: Stratigraphie von Deutschland V. Das Oberkarbon (Pennsylvanium) in Deutschland. - Courier Forschungsinstitut Senckenberg 254: 87-102.

Brauckmann, C. \& Herd, K. J. 2003. Insekten-Funde aus dem Westfalium D (Ober-Karbon) des Piesberges bei Osnabrück (Deutschland). Teil 1: Palaeoptera. - Osnabrücker Naturwissenschaftliche Mitteilungen 28 (for 2002): 27-69.

Brauckmann, C. \& Herd, K. J. 2006. Insekten-Funde aus dem Westfalium D (Ober-Karbon) des Piesberges bei Osnabrück (Deutschland). Teil 2: Neoptera. - Osnabrücker Naturwissenschaftliche Mitteilungen 30/31 (for 2005): 19-65.

Farley, R. 2001. Structure, reproduction and development. In Brownell, P. \& Polis G. A. (eds). Scorpion Biology and Research. Oxford University Press, Oxford: pp. 13-78.
Fet, V., Sissom, W. D., Lowe, G. \& Braunwalder, M. E. 2000. Catalog of the Scorpions of the World (1758-1998). The New York Entomological Society, New York.

Jeram, A. J. 1994a. Scorpions from the Viséan of East Kirkton, West Lothian, Scotland, with a revision of the infraorder Mesoscorpionina. - Transactions of the Royal Society of Edinburgh: Earth Sciences 84: 283-299.

Jeram, A. J. 1994b. Carboniferous Orthosterni and their relationship to living scorpions. - Palaeontology 37: 513-550.

Kjellesvig-Waering, E. N. 1986. A restudy of the Fossil Scorpionida of the World. - Palaeontographica Americana 55: 1-287.

Köwing, K. \& Rabitz, A. 2005. 4.1.3 Osnabrücker Karbon. In Deutsche Stratigraphische Kommission (ed.). Stratigraphie von Deutschland V. Das Oberkarbon (Pennsylvanium) in Deutschland. - Courier Forschungsinstitut Senckenberg 254: 255-270.

Meek, F. B. \& Worthen, A. H. 1868. Preliminary notice of a scorpion, a Eurypterus? and other fossils from the Coal Measures of Illinois and Iowa. - American Journal of Science and Arts 45: 25.

Nindel, F. 1955. Die tierischen Reste aus dem Karbon von KarlMarx-Stadt und Hainichen i. S. - Geologie 4 (7/8): 673-694.

Petrunkevitch, A. I. 1913. A monograph of the terrestrial Palaeozoic Arachnida of North America. - Transactions of the Connecticut Academy of Arts and Sciences 18: 1-137.

Petrunkevitch, A. I. 1953. Paleozoic and Mesozoic Arachnida of Europe. - Memoirs of the Geological Society of America 53: 1128

Rößler, R. \& Schneider, J. 1997. Eine bemerkenswerte Paläobiocoenose im Unterkarbon Mitteleuropas - Fossilführung und Paläoenviroment der Hainichen-Subgruppe (Erzgebirge-Becken). -Veröffentlichungen des Museums für Naturkunde Chemnitz 20: 5-44.

Scudder, S. H. 1884. A contribution to our knowledge of Palaeozoic Arachnida. - Proceedings of the American Academy of Arts and Science 20: 15-22.

Sterzel, J. T. 1918. Die organischen Reste des Kulms und Rotliegenden der Gegend von Chemnitz. - Abhandlungen der Mathematisch-Physikalischen Klasse der Königlich Sächsischen Gesellschaft der Wissenschaften 35 (5): 315 pp.

Woodward, H. 1907. Further notes on the Arthropoda of the British Coal Measures. - Geological Magazine 4: 539-549. 